\title{
Local populations of Sorbus torminalis (L.) Crantz in forest plantings of natural origin in the South-Podolsk Forest-Steppe of Ukraine
}

\author{
Nina Shpak, Volodymyr Shlapak, Svitlana Adamenko 凶, Yana Shvecs, Oleksandr Savchenko \\ Uman National University of Horticulture, UA - 20300 UMAN, Hlibka 19, Ukraine, e_mail: svitlanka0613@ukr.net
}

\begin{abstract}
The determination of factors that adversely affect the populations of rare plant species and development of measures to eliminate them are the important conditions for maintaining the rare component of natural flora. The article describes the study of forest phytocoenoses in the eastern territory of South-Podolsk Forest Steppe of Ukraine. The influence of natural conditions, morphological and physiological features of Sorbus torminalis (L.) Crantz on the distribution and population density in the studied region was analysed. The species is found in 80 quarters of different forestry districts with the population densities ranging from single to 300 individuals per hectare. The rare species has little prospect of natural seed restoration. The natural reforestation process of Sorbus torminalis is largely due to the specific conditions of phytocoenosis, age and vital structure of the forest stand. Most local populations have a low lifecycle. Very rare seed reproduction makes this species extremely vulnerable to the effects of any negative factors.

In the oak-hornbeam plantations, the plants of reproductive age prevail, but with the die-back of old individuals, the influx of renewal has almost disappeared. According to the results of the studied region, the oak plantations with Sorbus torminalis are found to have better values of the species distribution in the protected area compared to the recreational and economic ones (Sorbus torminalis remains in any sanitary condition in the plantations and on clean felling). Artificial resettlement should be carried out in places with a small projective cover of the vegetation, and Sorbus torminalis should be introduced into Quercus robur cultures as an associate species. This territory is the northeast boundary of the natural growth of the species.
\end{abstract}

\section{KeY WORDS}

coenopopulation, wild service tree, in-situ methods, gene preservation, Karmeliukove Podillia

\section{INTRODUCTION}

The need to assess the current state and trends of phytobiota change is determined by the increasing environmental impact of humans. The level of flora uniqueness can be characterized by quantitative and qualitative indices of the status of a rare phytogenic fund, which allows to organize adequate environmental measures. The protection of rare and endangered plant species is an integral part of a more general problem, namely the preservation and restoration of the natural environment and the rational use of its resources. 
Sorbus torminalis is a rare, extremely valuable native tree species, has decorative, curative qualities, is a good nectariferous plant. It has a very beautiful and strong wood, thick and very good crown, smooth and slender trunk, $22 \mathrm{~m}$ in height and even more. Its bark is greyish-brown, slightly cracked. The buds are glabrous, rounded oviform. The leaf blade is $16-18 \mathrm{~cm}$ long and $5-10 \mathrm{~cm}$ wide, rounded at the base, cuspidated at the apex, on each side with 3-5 (rarely 7) large pointed blades, which are roughly finely toothed on the laminas, with the lower pair of blades being cut off most deeply and horizontally remote. The young leaves are slightly pubescent - a biological adaptation of the plant to protect against excessive moisture loss and late spring frosts. After some time, when this threat is gone, the hairs fall off, the leaves are exposed and covered with a thin film - the cuticle. The leaves are dark green, glossy above, light green below, glabrous or pubescent only on the veins, of which the main vein and a pair of lateral pro- trusions appear most. Flowers are in dense, branched peltate inflorescences, which are small and 5-7 $\mathrm{mm}$ long. The perianth is white. The fruit is apple (similar to miniature apples), $12-15 \mathrm{~mm}$ long and $8-12 \mathrm{~mm}$ in diameter, first reddish-yellow, later reddish brown, brown with white dots and falling sepals, collected in clusters of 15-20 pieces. There are from 2 to 4 seeds in each apple. The seeds are inverted ovate, elongated, dark reddish-brown, 5-7 mm long, 3-4 $\mathrm{mm}$ wide. It blooms in April and May, fruiting in September and October. The fruiting starts from 18-20 years. In the forest plantations of the Karmeliukove Podillya NNP, the separate highyielding and big-fruited individuals of $S$. torminalis are found, yielding fruits with a high content of nutrients and vitamins. Here is a wide field of activity for their selection and introduction into culture. Up to $16 \mathrm{~kg}$ of fruit can sometimes be harvested from one tree. The seeds contain almost $22 \%$ of oil, the fruits up to $16 \%$ sugar. It propagates mainly by seeds, and it can form stool shoots.

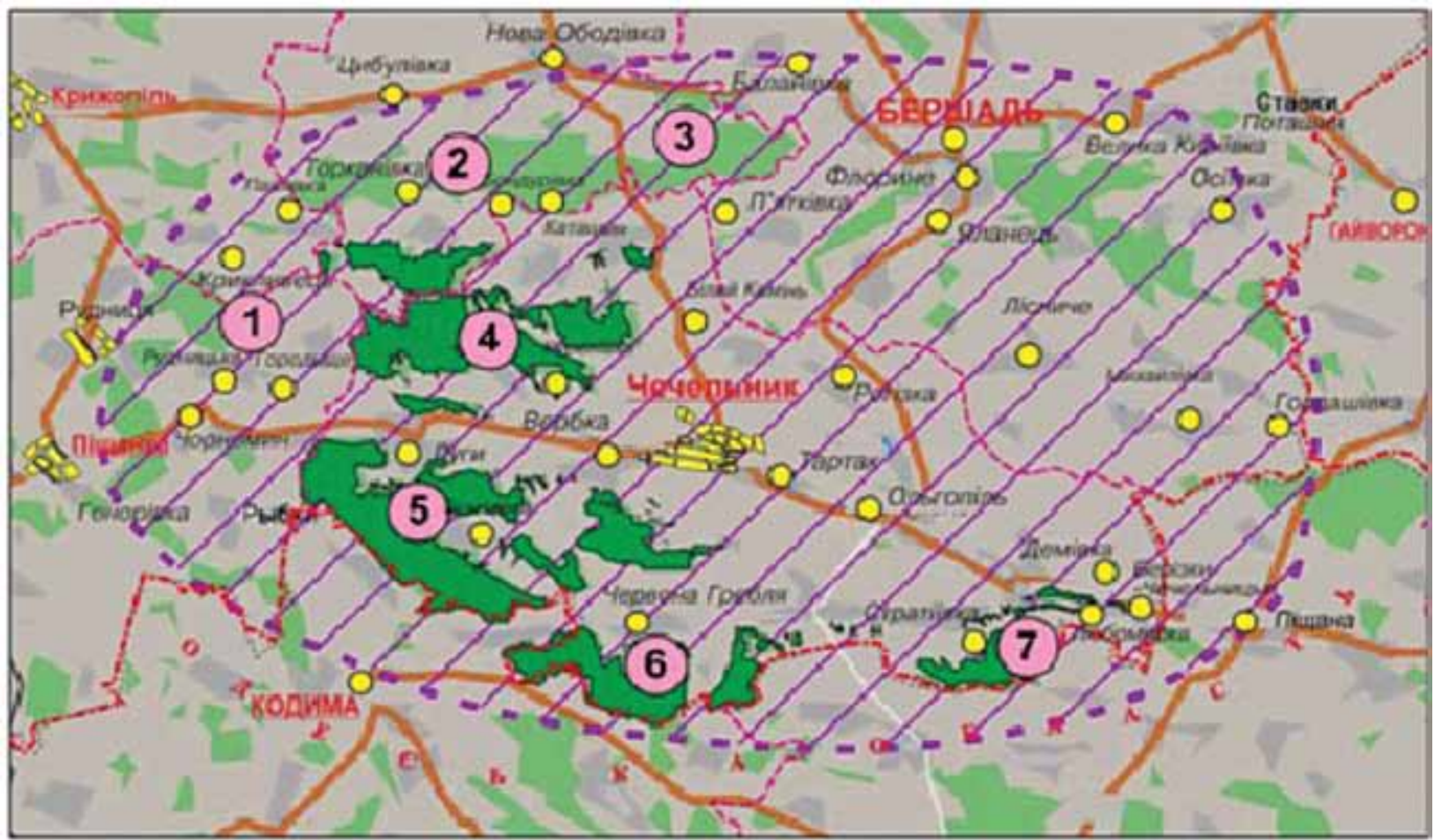

The studied region

(1) Forest districts where the research was carried out NNP "Karmeliukove Podillia"

Figure 1. Region of research on the of Sorbus torminalis distribution 
The natural and climatic conditions of the SouthPodolsk Forest Steppe of Ukraine are favourable for the distribution of species of plants and animals that need protection. Studying the biodiversity issues and conducting a detailed inventory, which is the basis of scientific research, enables monitoring at the regional and local levels.

According to the physical and geographical zoning of Ukraine, the studied region belongs to the Southern forest-steppe zone of Podolsk upland, which is part of the Dniester-Dnipro forest-steppe province of the Forest-Steppe zone of Ukraine. Geomorphologically, this area is associated with the southern slope of the Ukrainian Crystalline Shield. This territory, according to the geobotanical zoning of Ukraine, belongs to the Podolsk-Central Prydniprovsk sub-province of the Eastern European Province of the European-Siberian ForestSteppe Region and is located in the Kodymo-Savransk region of sessile oak, common oak forests and southern variants of meadow oak forests of Yampil-Ananiiv region of oak forests from sessile and common oaks, meadow oak forests, meadow steppes and vegetation of limestone deposits (Pogrebnyak 1993).

The research was conducted in the area that was restricted to the north by $48^{\circ} 26^{\prime} 00.0^{\prime \prime}$ north lat., in the south by $48^{\circ} 06^{\prime} 30.4^{\prime \prime}$. The most westerly point is $028^{\circ} 50^{\prime} 25.8^{\prime \prime}$, the most easterly point is $029^{\circ} 24^{\prime} 25.8^{\prime \prime}$. The complex geological history of the territory influenced the formation of the terrain, which is much carved, and the ravine and hollow systems are strongly developed. Absolute heights are up to $280 \mathrm{~m}$, the minimal ones (in the Savranka River valley) - $130 \mathrm{~m}$. Steppe landscapes were formed on forest rocks that are easily washed away by rain and melt water. Therefore, a typical feature of forest-steppe landscapes is the widespread development of ravines and hollows.

In the studied region, there is $400-440 \mathrm{~mm}$ of precipitation. The average annual temperature is 9.5 $-10.7^{\circ} \mathrm{C}$, the maximum is $34-42^{\circ} \mathrm{C}$, and the minimum is $14-25^{\circ} \mathrm{C}$. The deviation from the norm is +2.5 to $+4.1^{\circ} \mathrm{C}$.

The main soils of the area are grey forest loam and black soil. The fresh oak woods of South Podillia were formed on them. Such conditions are most favourable for the growth and development of many native and introduced tree species. Forests and other forested areas cover $14.3 \%$.
The works of Pyatnytskyi (1955), Soldatova et al. (1960), Kolisnichenko (2004), Hordienko and Shlapak (1998) are devoted to reafforestation in Podillia oak woods. Hordienko and Kovalevskyi (2006) highlight the effect of forest decline on the forest stands' productivity. The role of wild fruit plants in forest plantations was investigated by Ivanchenko (1952), Mahmet (1965), Budzhak (1996), Hordienko et al. (2006), Osipov and Leontiak (2013). The Pollen flow in the wild service tree was investigated by Oddou-Muratorio et al. (2005). The works of Demesure et al. (2000) are devoted to genetic variability of Sorbus torminalis L. The works of Rasmussen and Kollmann (2004) highlight the particularities of sexual reproduction of this species. The regional population dynamics was studied by Angelone et al. (2007).

The purpose of the research was to study the current state of the population of the endangered species Sorbus torminalis (L.) Crantz and to preserve the plant in the ex situ system.

Objectives: to analyse the state of natural plantations with Sorbus torminalis; dynamics of quantitative and qualitative state of the species in terms of fresh oak-hornbeam woods; to draw attention to the implementation of a number of forest management measures for the preservation and restoration of $S$. torminalis in the region; prospects for use in landscape design.

In order to achieve the maximum effect and coordination of actions on protection and preservation of the endangered species in the Karmeliukowe Podillia National Nature Park, the 'Program on preservation and reproduction of Sorbus torminalis (L.) Crantz on the territory of Karmeliukowe Podillia National Nature Park for 2018-2021' was developed and specific measures in the focus area were identified. The park was founded in accordance with the Presidential Decree of Ukraine No. 1057/2009 of December 16, 2009; its total area is 20203.4 ha.

The object of the research $\mathrm{s}$ the oak-hornbeam stands of natural origin (large in area), with a well-represented core of Sub Mediterranean and Balkan species.

\section{Materials AND Methods}

The subject of the research is the ecological features and effective methods of application of forestry techniques for the preservation and reproduction of such natural 
plantations in the conditions of the South Podolsk Forest Steppe of Ukraine.

In 2015-2019, 64 temporary and 11 permanent sample plots were laid in the Bershad, Kryzhopil, Chechelnitsky forest husbandries of Vinnytsia region for the stationary studies of forest phytocoenoses with Sorbus torminalis. The main methods of the research were: detailed route maps, mapping of species' locations; forest inventory, ecological-phytocenotic description of species and plant groups. The sample plots were laid according to the conventional methods of forestry by Alekseeva (2003) and Anuchina (1977). To determine the forestry and taxation indices of forest stand, undergrowth, new growth, grass cover and soil varieties, the applications from the Forestry Workshop, edited by Svyrydenko et al. (2006) were used. The taxonomic composition of the research objects was specified using the following references: Atlas of Trees and Shrubs of Ukraine (1973) and Determinant of Higher Plants. For the characterization of stands, the 'Regulatory reference materials for taxation of forests in Ukraine and Moldova' were used (1987). The monitoring of the natural species regeneration was carried out according to the method of UkrNDILGA (1976), according to which, the discount areas were laid, which annually record the species composition of the new growth, its number, height, age groups and viability (2011). In the research, the plant names are given according to the guide of higher plants of Ukraine. The categories of trees were determined according to the scale 'Sanitary rules in the forests of Ukraine.'

In the first stage of the research, during the route surveys and further study of the literature on the formation of forest stands in Podillia forests, they were conducted within the Karmeliukowe Podillia National Nature Park.

\section{Results AND Discussion}

The Pan-European Biological and Landscape Diversity Strategy, adopted in 1995 in Sofia, provides reliable protection of plant and animal species, unique landscapes in all the regions of Europe, in the context of sustainable development, as well as the creation of a pan-European ecological network in which nature preservation areas play a special role. Many species have become rare due to disruption of natural systems and natural interconnections between organisms. S.M. Stoiko (2018) believes that the natural renewal indices serve as a kind of test for the species' vitality. Among the factors that affect the dynamics of renewal, the most important is the storied structure of coenosis, its completeness, density and species composition of undergrowth and new growth, the nature of the grass cover. The ploughness of the studied area, at present, reaches about $65 \%$ of the total area of farmland. Due to anthropogenic influence, namely: ploughing of steppe and meadow biocenoses, deforestation, banking up of river beds, drying of marsh complexes, the territory is significantly fragmented.

As a result of overuse of natural biodiversity, the process of losing its biological stability and displacing valuable species of flora and fauna continues to occur.

Within the framework of the implementation of the Regional Eco-Network Program, the habitats of plants and animals listed in the Ukraine Red Data Book and regionally rare species were identified. Based on the flora inventory, systematic lists of vascular plants have been compiled, including a number of valuable rare, endemic, relict and border-areal species. The third edition of the Ukraine Red Data Book presents one of such species Sorbus torminalis L. Crantz, which belongs to the genus Sorbus L., family Rosaceae, class Magnoliopsida, division Magnoliophyta. The preservation status of the species is unpriced. Scientific importance: endangered species.

The reason for change in the number of S. torminalis was the felling of mixed broad-leaved forests and their replacement by monocultures, selective felling of trees as valuable wood, for the manufacture of furniture. Landscaping experts appreciate $S$. torminalis for its slender and unusual leaves, which look like maple leaves and are bright orange in autumn. The species is protected on the territory of such nature reserves as Yalta mountain-forest nature reserve, Karadag, Crimean and 'Medobory' reserves; the national nature parks 'Podilski Tovtry' and 'Karmeliukove Podillia', RLP 'Chernivtsi', 'Dniester Canyon'; in nature reserves and natural monuments of Chernivtsi, Ivano-Frankivsk, Ternopil and Vinnitsa regions. The selective felling of S. torminalis, destruction of growth sites is prohibited. It is grown in many botanical gardens and arboretums in Ukraine. Almost 10 countries, among them Ukraine, have included this tree in the Red Data Book. 
The basis of the research is the analysis and assessment of the state of uneven-aged oak stands of seed origin on the dynamics of forestry and inventory indices. The dominant forest species in the stands are Quercus robur, Quercus retraea, Fraxinus excelsior, which form the bulk of the forest fund and form the first storey. The Carpinus betulus, with the admixtures of Tilia cordata, Acer platanoides, Acer campestre, Ulmus campestris, Ulmus glabra, Cerasus avium and Sorbus torminalis dominate in the second storey. The derived types of plantations are represented by the forest stand with the Carpinus betulus preference.

The scientific value of these forests is of considerable importance in the forest stand of Quercus retraea, Sorbus torminalis and in the undergrowth - Sornus mas. In the surviving plantations in the ground cover, there are species listed in the Red Data Book of Ukraine, such as: Cephalanthera damasonium, Euonymus nana, Securigera elegans, Neottia nidus-avis, Lilium martagon, Platanthera bifolia, Galanthus nivalis, Tulipa quercetosum, and so on.

The undergrowth is formed of such eutrophic plants as Corylus avellana, Viburnum lantana, Crataegus monogyna, Crataegus oxycantha, Euonymus europaea, Cornus mas, and so on. Carpinus betulus, Fraxinus excelsior, Acer platanoides, Acer campestre prevail in the new growth. The projective cover of herbaceous plants is $10-70 \%$ with preference of Galium verum, Carex brevicollis, Allium ursinum, Gagea lutea, Asarum europaeum, Pulmonaria obscura.

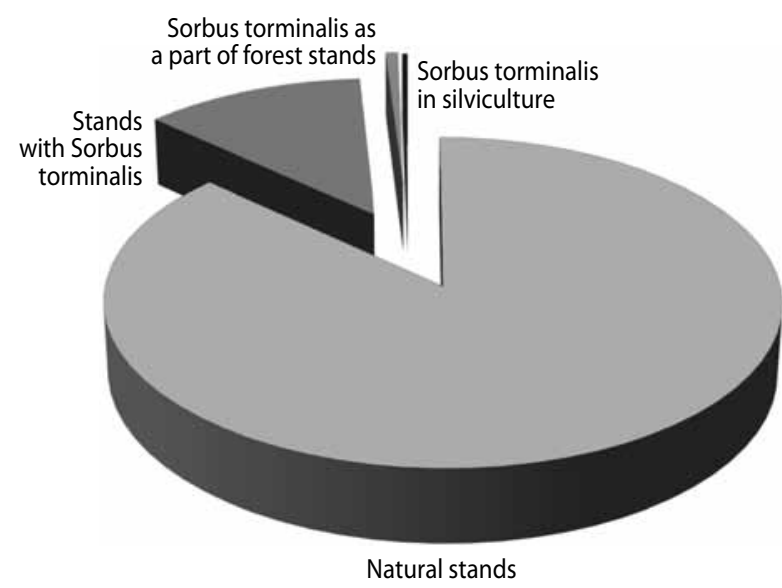

Figure 2. Sorbus torminalis in natural and artificial stands
Sorbus torminalis is the most common in the natural stands of natural seed origin and makes 2435.8 ha (5.3\% of the area covered by forest vegetation) (Fig. 2).

S. torminalis as a part of forest stands (1-3 units) occurs in the sections of 15 quarters, spreading due to cessation of felling. It is most often found in mature plantations $-51.3 \%$, rarely in young plants $-11.9 \%$ of the total planted area with its participation. Over the last 10 years, it has been introduced into Quercus robur crops on an area of more than 50 ha.

The interaction of tree species in stands is characterized by dynamism and is different. Co-growth with Quercus robur is favourable for Sorbus torminalis. The Tilia cordata, Acer platanoides and Acer campestre, a small part of Carpinus betulus and other species play a positive role in the composition of oak stands. Thus, the maximum phosphorus uptake coincides with the highest excretion of this element by Acer platanoides and Sorbus torminalis. The admixture of Sorbus torminalis emits a significant amount of potassium, Carpinus betulus contributes to the acidity of the soil solution, which helps to intensify the circulation of food compounds. This is important in black earth soils. The oak stands' composition is shown in Table 1.

The trends on decreasing the density with aging were not found. According to the Kraft scale the III-d class trees prevail (40\%), I - 3\%, II - 16\%, IV - 38\%, $\mathrm{V}-1 \%$, VI $-2 \%$. The average stock of age-old oak stands is $320 \mathrm{~m}^{3}$. A positive role in the preservation of the age-old plantations of Quercus robur was played by the fact that in 1990, a botanical reserve of national importance 'Brytavskyi' was founded on this territory (Resolution of the Council of Ministers of the USSR No.123) with the area of 3,259 ha, which makes 55.1\% of the Brytavskyi Forestry ecosystem. Permanent seed plantations of Quercus robur and Sorbus torminalis are laid here. The assessment of the sanitary condition of plantations growing in the reserve has shown that healthy trees predominate. Among 174 diseased and damaged trees (2.9\%), there are 46 with lumbar cancer, 8 with bracket fungus, 54 with water shoot, 28 with rot root, 6 with hollows, 26 with broken top, 6 damaged with oak silkworm. Individuals of $S$. torminalis have been found to have mechanical damage with lumbar cancer and fungi. Previously, such diseases (according to foresters) were not encountered. The data obtained in the territory of forestries (Brytavske, Dokhnianske and 
Table 1. Inventory indices of preserve the oldest oak stands of natural seed origin

\begin{tabular}{|c|c|c|c|c|c|c|c|c|c|}
\hline \multirow[b]{2}{*}{ № } & \multirow{2}{*}{$\begin{array}{l}\text { Quarter, } \\
\text { unit }\end{array}$} & \multirow[b]{2}{*}{ Stand composition* } & \multirow{2}{*}{$\begin{array}{c}\text { Age, } \\
\text { in years }\end{array}$} & \multirow{2}{*}{$\begin{array}{c}\text { Class of } \\
\text { productivity }\end{array}$} & \multicolumn{2}{|c|}{ Average } & \multirow{2}{*}{$\begin{array}{l}\text { Basal } \\
\text { area, } \\
\mathrm{m}^{2} \text { ha }\end{array}$} & \multirow{2}{*}{$\begin{array}{l}\text { Relative } \\
\text { density }\end{array}$} & \multirow{2}{*}{$\begin{array}{l}\text { Stock } \\
\mathrm{m}^{3} \text { ha }\end{array}$} \\
\hline & & & & & $\begin{array}{c}\text { Height, } \\
\mathrm{m}\end{array}$ & $\begin{array}{c}\text { Diameter, } \\
\mathrm{cm}\end{array}$ & & & \\
\hline 1 & $63 / 1$ & $6 \mathrm{Co} 2 \mathrm{Ch} 2 \mathrm{Ca}+\mathrm{Fm}+\mathrm{Fe}+\mathrm{Wst}$ & 130 & II & 27 & 40 & 17,86 & 0,70 & 310 \\
\hline 2 & $42 / 1$ & $8 \mathrm{Co} 2 \mathrm{Ch}+\mathrm{Ca}+\mathrm{Fm}+\mathrm{Fe}+\mathrm{Wch}+\mathrm{Wst}$ & 120 & I & 25 & 36 & 24.09 & 0,70 & 385 \\
\hline 3 & $103 / 1$ & $7 \mathrm{Co} 2 \mathrm{Ca} 1 \mathrm{Ch}+\mathrm{Fm}+\mathrm{Fe}+\mathrm{Wch}+\mathrm{Wst}$ & 130 & I & 27 & 40 & 23,12 & 0,65 & 335 \\
\hline 4 & $94 / 1$ & $7 \mathrm{Co} 2 \mathrm{Ch} 1 \mathrm{Ca}+\mathrm{Fm}+\mathrm{Fe}+\mathrm{Chl}+\mathrm{Wst}$ & 110 & II & 25 & 36 & 25,32 & 0,75 & 310 \\
\hline 5 & $82 / 1$ & $6 \mathrm{Co} 1 \mathrm{Ch} 3 \mathrm{Ca}+\mathrm{Fm}+\mathrm{Fe}+\mathrm{Wch}+\mathrm{Wst}$ & 130 & I & 26 & 36 & 23,56 & 0,70 & 320 \\
\hline 6 & $77 / 4$ & $5 \mathrm{Co} 3 \mathrm{Ch} 1 \mathrm{Ca} 1 \mathrm{Fe}+\mathrm{Fm}+\mathrm{Chl}$ & 120 & $\mathrm{I}^{\mathrm{a}}$ & 26 & 38 & 20,46 & 0,60 & 280 \\
\hline 7 & $68 / 2$ & $5 \mathrm{Co} 3 \mathrm{Ch} 2 \mathrm{Ca}+\mathrm{Fm}+\mathrm{Chl}$ & 135 & II & 26 & 40 & 22,74 & 0,60 & 300 \\
\hline \multicolumn{5}{|c|}{$\mathrm{LSD}_{0,95}$} & 1,01 & 3,98 & & 1,05 & \\
\hline
\end{tabular}

* $-\mathrm{Ca}$ - common ash; $\mathrm{Ch}$ - common hornbeam; Chl - common hazel; Co - common oak; Fe - field elm; Fm - field maple; Wch - wild cherry; Wst - wild service tree.

Table 2. Inventory indices of preserve the oldest oak stands of natural seed origin in forest districts

\begin{tabular}{|c|c|c|c|c|c|c|c|c|c|c|}
\hline \multirow[b]{2}{*}{ № } & \multirow{2}{*}{$\begin{array}{l}\text { Quarter, } \\
\text { unit }\end{array}$} & \multirow[b]{2}{*}{ Stand composition ${ }^{*}$} & \multirow{2}{*}{$\begin{array}{l}\text { Stand composition } \\
\text { after felling care }\end{array}$} & \multirow{2}{*}{$\begin{array}{l}\text { Age, } \\
\text { in } \\
\text { years }\end{array}$} & \multirow{2}{*}{$\begin{array}{l}\text { Class of } \\
\text { produc- } \\
\text { tivity }\end{array}$} & \multicolumn{2}{|c|}{ Average } & \multirow{2}{*}{$\begin{array}{l}\text { Basal } \\
\text { area, } \\
\mathrm{m}^{2} \text { ha }\end{array}$} & \multirow{2}{*}{$\begin{array}{l}\text { Rela- } \\
\text { tive } \\
\text { density }\end{array}$} & \multirow[b]{2}{*}{$\begin{array}{l}\text { Stock, } \\
\mathrm{m}^{3} \text { ha }\end{array}$} \\
\hline & & & & & & $\begin{array}{l}\text { height, } \\
\text { m }\end{array}$ & $\begin{array}{c}\text { diameter, } \\
\mathrm{cm}\end{array}$ & & & \\
\hline 8 & $22 / 6$ & $\begin{array}{l}8 \mathrm{Co} 1 \mathrm{Ca} 1 \mathrm{Ch}+ \\
+\mathrm{Fm}+\mathrm{Wst}+\mathrm{Chl}\end{array}$ & $\begin{array}{l}6 \mathrm{Co} 2 \mathrm{Ch} 2 \mathrm{Ca}+\mathrm{Fm}+ \\
+\mathrm{Chl}+\mathrm{Wch}+\mathrm{Fe}+\mathrm{Wst}\end{array}$ & 100 & II & 27 & 30 & 18,77 & 0,55 & 210 \\
\hline 9 & $51 / 7$ & $\begin{array}{l}6 \mathrm{Co} 3 \mathrm{Ca} 1 \mathrm{Ch}+\mathrm{Wch}+ \\
+\mathrm{Fm}+\mathrm{Chl}+\mathrm{Wst}\end{array}$ & $\begin{array}{l}\text { 3Co4Ch1Ca1Fm + 1Fe }+ \\
+ \text { Chl }+ \text { Wch }+ \text { Wst }\end{array}$ & 105 & III & 26 & 32 & 16,72 & 0,65 & 260 \\
\hline 10 & $41 / 7$ & $\begin{array}{l}\text { 7Co2Ca1Ch }+ \\
+\mathrm{Chl}+\mathrm{Fm}+\mathrm{Wch}\end{array}$ & $\begin{array}{l}\text { 4Co4Ch1Fm } 1 \text { Wch }+\mathrm{Ca}+ \\
+\mathrm{Chl}++\mathrm{Fe}+\mathrm{Wst}\end{array}$ & 101 & II & 25 & 32 & 20,45 & 0,50 & 220 \\
\hline 11 & $10 / 6$ & $\begin{array}{l}6 \mathrm{Co} 2 \mathrm{Ch} 2 \mathrm{Ca}+ \\
+\mathrm{Fm}+\mathrm{Wch}+\mathrm{Wst}\end{array}$ & $4 \mathrm{Co} 6 \mathrm{Ch}+\mathrm{Fm}+\mathrm{Wch}$ & 100 & II & 24 & 36 & 18,67 & 0,60 & 250 \\
\hline 12 & $11 / 1$ & $\begin{array}{l}4 \mathrm{Co} 3 \mathrm{Ca} 3 \mathrm{Ch}+\mathrm{Chl}+ \\
+\mathrm{Wst}\end{array}$ & $\begin{array}{l}4 \mathrm{Co} 4 \mathrm{Ch} 2 \mathrm{Ch}+\mathrm{Wch}+ \\
+\mathrm{Fm}+\mathrm{Chl}+\mathrm{Fe}+\mathrm{Wst}\end{array}$ & 110 & II & 24 & 36 & 17,45 & 0,65 & 245 \\
\hline \multicolumn{4}{|c|}{$\operatorname{LSD}_{0,95}$} & & & 2,05 & 2,38 & & & \\
\hline
\end{tabular}

${ }^{*}-\mathrm{Ca}$ - common ash; $\mathrm{Ch}$ - common hornbeam; Chl - common hazel; $\mathrm{Co}$ - common oak; Fe - field elm; Fm - field maple; Wch - wild cherry; Wst - wild service tree

Chervonohrebelske) illustrate that the dynamics of forest stands change after various economic interventions (Tab. 2).

The number of oldest oak trees has decreased significantly; oak-hornbeam stands are gradually moving into hornbeam-ash-oak ones. The III-d class trees prevail (42\%), I - 1.9\%, II - 20\%, IV - 29\%, V - 3.6\%, VI $-2.1 \%$. The average stock of the oldest oak stands is $237 \mathrm{~m}^{3}$. There is a tendency for trees of different breeds to dry. For 4 years, 1 to $3 S$. torminalis trees that have fallen from the stand (category VI) have been found in the permanent sample plots.
The network of plots of Quercus robur of natural seed origin with Sorbus torminalis and Cornus mas in ecosystems can become the base of a preserved area, a landfill for scientific research.

For the study of stands with S. torminalis, 64 sample plots in different age categories of the forest stand were found (2015-2019) (young, middle-age, half-mature, mature and over-seasoned ones), as well as 11 permanent sample plots and a monitoring site. The quantitative ratio of $S$. torminalis (with predominance of trees with a diameter of $8-16 \mathrm{~cm}$ ) in different woodlands is presented in the summary Figure 3. 
In young forest stands, $Q$. robur, F. excelsior quantitatively dominate in the first tree storey and $C$. betulus, A. campestre, T. cordata and S. torminalis $(5-8 \%)$ in the second tree storey with a diameter of 8-16 cm (IVth category). In the quadrate $66 / 4$, there are no reproductive individuals of $S$. torminalis - this indicates that the seeds have been brought by the birds from other areas. In the middle-age and half-mature stands of natural origin, the number of $Q$. robur and $F$. excelsior decreased in comparison with inventory data, and the number of C. betulus, A. platanoides increased in the second storey (Q 66/8; 82/3; 86/7), S. torminalis is a part of the stand and makes $14-22 \%$ with the predominance of trees with a diameter of $12-20 \mathrm{~cm}$, which indicates the rejuvenation of this breed. Certain individuals of $S$. torminalis with a trunk diameter of $32-44 \mathrm{~cm}$ are found in some quadrates, but not all of them are reproductive. The seed plantations on the forest borders and open areas with a relative thickness of $0.4-0.5$ contribute to the restoration of $S$. torminalis. In the age plantations, we trace the decrease in the number of checker tree self-seeding, which eventually completely falls out of the new growth, one or three years of self-seeding in these areas is not found. Perennial plantations do not have a large variety of tree species. The diversity of the new growth in such natural plantations is insignificant, the preference of the

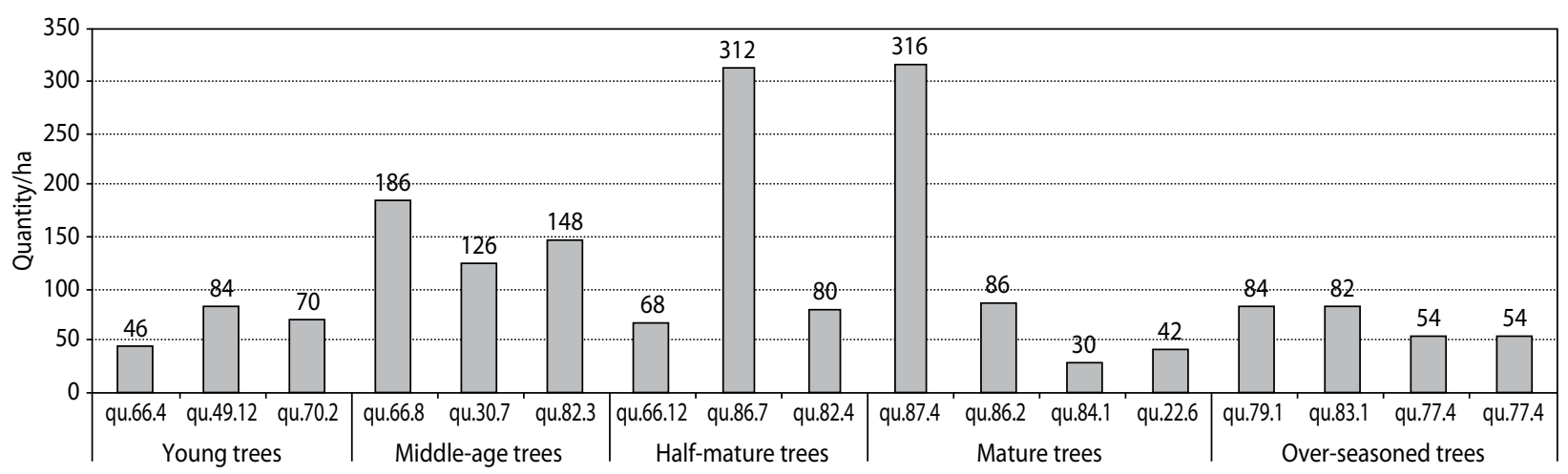

Figure 3. Quantitative ratio of Sorbus torminalis L. in different age categories of stands (diameter 8-16 cm)

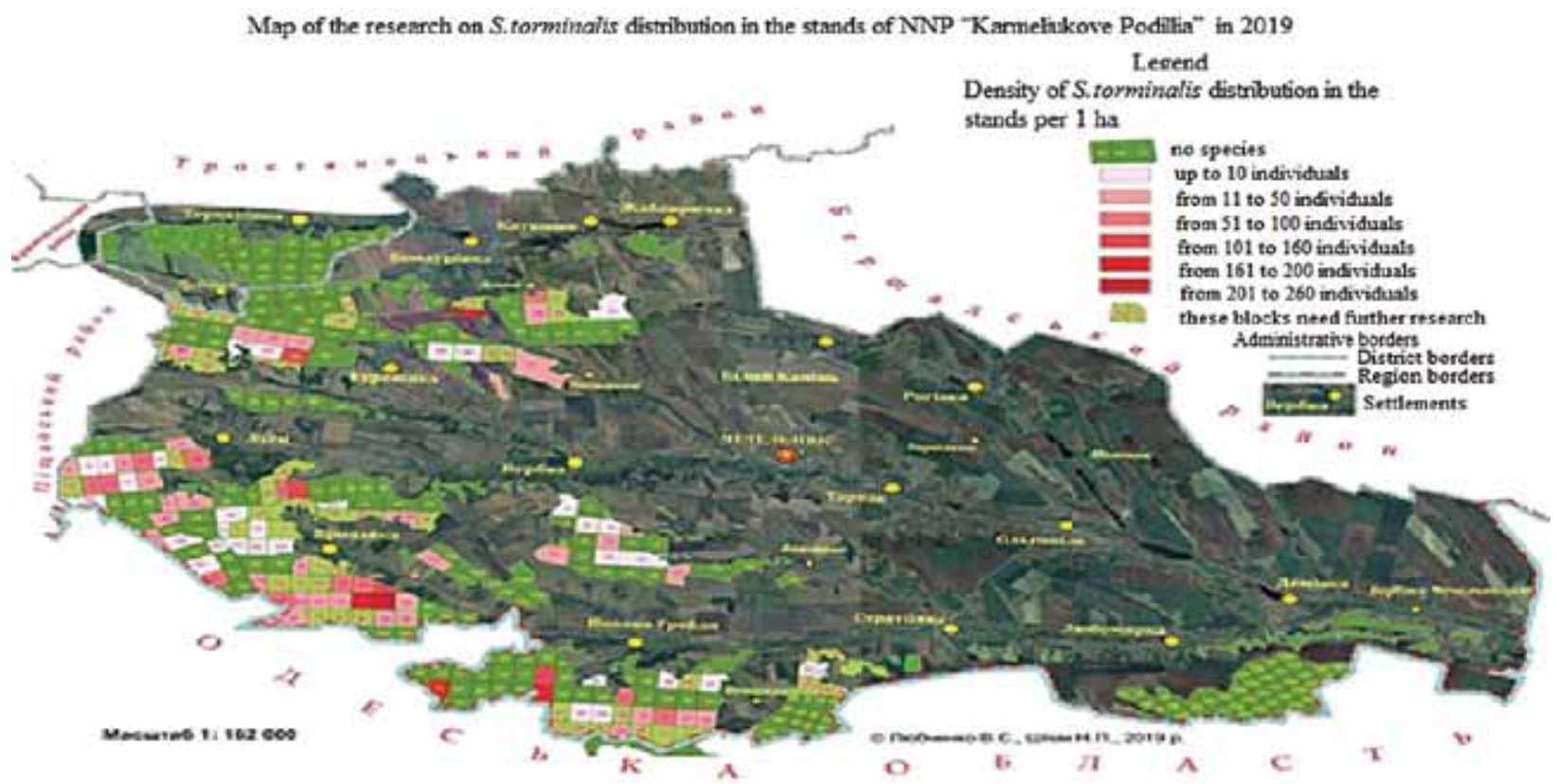

Figure 4. Distribution and density of $S$. torminalis in stands 
C. betulus new growth was caused by the absence of seedlings and the fall of the new growth of $S$. torminalis, dominated by Carex umbrosa curds in the grass cover.

The uneven distribution of $S$. torminalis depends on the age and composition of the stands, the topography, the genetic type and the mechanical composition of soil and other natural factors. The stand composition plays a decisive role in the formation of storeys and the place of $S$. torminalis in the stands. Fast-growing timber trees inhibit it until it reaches the second storey. Young shoots, with a trunk diameter of $4-6 \mathrm{~cm}$, are difficult to break through thick shelterwood, and insufficient moisture in summer causes them to dry out. Figure 4 shows the distribution and density of $S$. torminalis in the studied area.

S. torminalis was found in 82 quadrates, 140 units, its density in stands ranges from single individuals to 316 individuals/ha.

Scientists and foresters did not pay due attention to the peculiarities of the reproductive development of $S$. torminalis, the issue remained open. In 2015, in the Brytavske Forestry, the sample plots were laid to determine the quantitative and qualitative characteristics of wild service tree fruiting. In order to study the amount of natural material, for the restoration of the species, the annual analysis of $S$. torminalis fruiting was carried out at an individual level. 27 permanent sample plots in 4 quarters were laid in accordance with the selected samples, which bore fruit in 2015. S. torminalis was numbered according to field research requirements on the permanent sample plots. 9 sites with the area of $1 \mathrm{~m}^{2}$ were laid radially from the trunk to the edge of crown projection. Generally,
108 sites were laid. From the second half of August, all the fruits were collected at the sites and visually divided by quality: ripe, damaged and immature. The examinations were performed every 10 days until the fruit was completely dropped (October). The fruiting intensity of each tree and the ratio of different quality fruits were determined. The results of fruiting are given in Table 3.

The dry years 2015-2017 (with the predominance of hot days) contributed to the early ripening of fruit and their rapid fall. The fruits are small, mostly with one seed. After the previous dry years, in 2018, the S. torminalis yields were relatively high, due to moist, warm summers, with relatively large, juicy fruits with two or three ripe seeds.

Comparing the size and weight of the harvested fruits, it was found that the fruits in oak-ash stands were the smallest, the average weight of the fruit was $0.98 \mathrm{~g}$, the abundance of fruiting was low (less than $3 \mathrm{~kg}$ from a 40-year-old tree); in oak-hornbeam stands, the average fruit weight was $1.33 \mathrm{~g}$, the abundance was average, but in trees that grow on the wood edges, the abundance was $6-8 \mathrm{~kg}$ from $30-40$ year-old trees. Two large-fruited individuals of $S$. torminalis were found on the wood edge in the quarter 90 , unit 4 , with a fruit weight of 2.58-3.21 $\mathrm{g}$ and high abundance. $12.5 \mathrm{~kg}$ of fruits were harvested from one 40 year-old tree (2018), with an average number of 400 fruits per kilogram. The peculiarity of the species is revealed - after abundant fruiting, in 2019 in the studied region and adjacent territories, there was no yield at all.

Yielding years are much less common than the mass flowering years. According to the terms of morphologi-

Table 3. Indices of flowering and fruiting biology of S. torminalis in fresh oak and hornbeam woods

\begin{tabular}{|c|c|c|c|c|c|c|}
\hline Years & $\begin{array}{l}\text { Flowering } \\
\text { period }\end{array}$ & $\begin{array}{l}\text { Fruit ripening } \\
\text { period }\end{array}$ & $\begin{array}{l}\text { Beginning } \\
\text { of fruit fall }\end{array}$ & $\begin{array}{c}\text { Average weight } \\
\text { of } 1000 \text { pcs. fruits, } g\end{array}$ & $\begin{array}{c}\text { Average weight } \\
\text { of } 1000 \text { pcs. seeds, } g\end{array}$ & $\begin{array}{c}\text { Number of fruits } \\
\text { in } 1 \mathrm{~kg}\end{array}$ \\
\hline 2014 & $10-22.05$ & $\begin{array}{l}\text { August- } \\
\text { September }\end{array}$ & the end of August & $800 \pm 0.35$ & $21.8 \pm 0.31$ & $1256 \pm 0.24$ \\
\hline 2015 & $14-25.05$ & July, $3^{\text {rd }}$ decade & August, $2^{\text {nd }}$ decade & $762 \pm 0.23$ & $19.9 \pm 0.43$ & $1318 \pm 0.36$ \\
\hline 2016 & $16-27.05$ & $\begin{array}{l}\text { August- } \\
\text { September }\end{array}$ & $\begin{array}{l}\text { September, } 2^{\text {nd }} \\
\text { decade }\end{array}$ & $907 \pm 0.15$ & $21.6 \pm 0.27$ & $1102 \pm 0.25$ \\
\hline 2017 & $07-22.05$ & July, $2^{\text {nd }}$ decade & August, $1^{\text {st }}$ decade & $626 \pm 0.54$ & $17.4 \pm 0.34$ & $1497 \pm 0.47$ \\
\hline 2018 & $12-25.05$ & $\begin{array}{l}\text { September- } \\
\text { October }\end{array}$ & $\begin{array}{c}\text { September, } 3^{\text {rd }} \\
\text { decade - October }\end{array}$ & $1319 \pm 0.29$ & $24.4 \pm 0.55$ & $758 \pm 0.18$ \\
\hline 2019 & $05-15.05$ & no & - & - & - & - \\
\hline
\end{tabular}


cal ripeness, the seeds of the species can be attributed to the third group - breeds with the seeds ripening in late summer-early autumn (late August-September). Deep seed dormancy (2-8 months), strong mature seed skin, lack of endosperm (epigeal cotyledons perform photosynthetic function, lack of long snow cover, insufficient moisture and high temperatures in spring and summer, litter density and depth is an incomplete list of reasons of poor restoration of the species in natural conditions.

The beginning of fruiting of a wild service tree comes after the age of 20 (in forest plantation of 16-18 years). The success of wild service tree restoration depends on the density of the second storey of tree species and undergrowth. As the second storey closes and the new growth of other tree and shrub species decreases, the total number of self-seeding and new growth increases.

The success rate of Sorbus torminalis renewal in fresh oak forests is unsatisfactory (under the Gorshenin 1977 scale). The renewal of $S$. torminalis under a shelterwood is of curtinous character, with the self-seeding occurring mainly in stands of 6-8 units of Quercus robur, 2-3 units of Carpinus betulus, 1-2 units of Fraxinus excelsior. Reafforestation on continuous felling sites is almost absent. In the first year, we see the emergence of self-seeding, but under the influence of high temperatures in summer, there is a drying up of the soil, the growth of long-day herbaceous plants and seedlings damage during the crop care works. Under a shelterwood of the forest stand, the young generation of S. torminalis survives at a fullness of 0.6-0.7. Quercus robur does not inhibit the new growth of $S$. torminalis and their root systems in the rhizosphere are compatible. Ulmus and Sorbus root systems are not compatible. The prevalence of Carpinus betulus in the new growth and in forest stands displaces the Quercus robur and Sorbus torminalis. The number of seedlings within the crown projection is from 3 to 16 pieces $/ \mathrm{m}^{2}$, and outside the crown, at a distance of 100-150 m, 3-4 seedlings. In the first growing season, in fresh oak woods, the seedlings reach a height of 3-5 cm and have 3-4 leaves (Fig. 5).

In the first five years, we observe weak growth energy of the wild service tree top. Growth in height reaches 1.6 to $3.5 \mathrm{~cm}$ during the growing season. The number of leaves increases from 3 to 7 . After 6-8 years of age, the growth energy is $48-72 \mathrm{~cm}$ per year, there is a stem branching and there is the formation of densely-leaved crown. The trunk bark of 10-15 year-old trees forms longitudinal shallow cracks from the root neck and gradually along the height of the trunk to the branching of the skeletal branches, this feature is typical for the species. Up to 35 years, the crown is oval with elongated apex. Over the years, the apex of the crown becomes more rounded. After the age of 50, the growth in height slows down, the crown diameter increases. In 15 year-old trees, the crown diameter is $1.8 \mathrm{~m}$, in 30 year-old $-2.1-2.4 \mathrm{~m}$, in 50 year-old $-3.0-6 \mathrm{~m}$, in 70 year-old $-4-6.5 \mathrm{~m}$, in 100 year-old $-8-9 \mathrm{~m}$. Up to $30-35$ years, $S$. torminalis has the same height as $Q$. robur. $S$. torminalis leafy crown protects the $Q$. robur crown from the sides and later promotes the removal of $Q$. robur trees from the branches.

Table 4. Number of self-seeding of wild service tree depending on the second storey density of tree species

\begin{tabular}{|c|c|c|c|c|c|c|c|}
\hline \multirow{2}{*}{ Forestry, quarter } & \multirow{2}{*}{$\begin{array}{l}\text { Composition of the forest stand } \\
\text { second storey* }\end{array}$} & \multirow{2}{*}{ Density } & \multicolumn{5}{|c|}{ Number of self-seeding by age groups, pcs/ha } \\
\hline & & & $1-2 \mathrm{p}$. & $3-5 \mathrm{p}$. & 6-9 p. & $10-15 \mathrm{p}$. & Total \\
\hline Brytavske, $60 / 1$ & 9Ch1Fm $+\mathrm{Chl}+\mathrm{Co}+\mathrm{Ca}+\mathrm{Wst}$ & 0.6 & 30 & 8 & 6 & 0 & \\
\hline Brytavske, 32/1 & $8 \mathrm{Ch} 2 \mathrm{Fm}+\mathrm{Co}+\mathrm{Ca}+\mathrm{Chl}+\mathrm{Wst}$ & $0.4-0.5$ & 16 & 12 & 20 & 12 & 60 \\
\hline Brytavske,96/1 & 7Ch2Chl1Fm $+\mathrm{Co}+\mathrm{Ca}+\mathrm{Wst}$ & 0.5 & 20 & 8 & 12 & 6 & 46 \\
\hline Brytavske, woodline & 9Ch1Fm $+\mathrm{Co}+\mathrm{Ca}+\mathrm{Chl}+\mathrm{Wst}$ & 0.3 & 48 & 32 & 20 & 18 & 118 \\
\hline Chervonohrebelske $34 / 2$ & $4 \mathrm{Co} 3 \mathrm{Ch} 2 \mathrm{Ca} 1 \mathrm{Chl}$ & $0.7-0.8$ & 8 & 14 & 5 & 0 & 27 \\
\hline Chervonohrebelske51/1 & $4 \mathrm{Ca} 3 \mathrm{Ch} 2 \mathrm{Fm} 1 \mathrm{Chl}+\mathrm{Wst}$ & 0.5 & 0 & 16 & 18 & 12 & 46 \\
\hline Dohnianske, $82 / 4$ & 4Ch3Ca1Chl1 Fm + Wst $+\mathrm{Fe}$ & 0.4 & 22 & 18 & 16 & 8 & 64 \\
\hline Dohnianske, $36 / 11$ & 5Wst3Ch1Ca1 Fm & 0.4 & 0 & 32 & 30 & 140 & 202 \\
\hline $\mathrm{LSD}_{0,95}$ & & & & & & & 2.98 \\
\hline
\end{tabular}

* $-\mathrm{Ca}$ - common ash; $\mathrm{Ch}$ - common hornbeam; Chl - common hazel; Co - common oak; Fe - field elm; Fm - field maple; Wch - wild cherry; Wst - wild service tree 


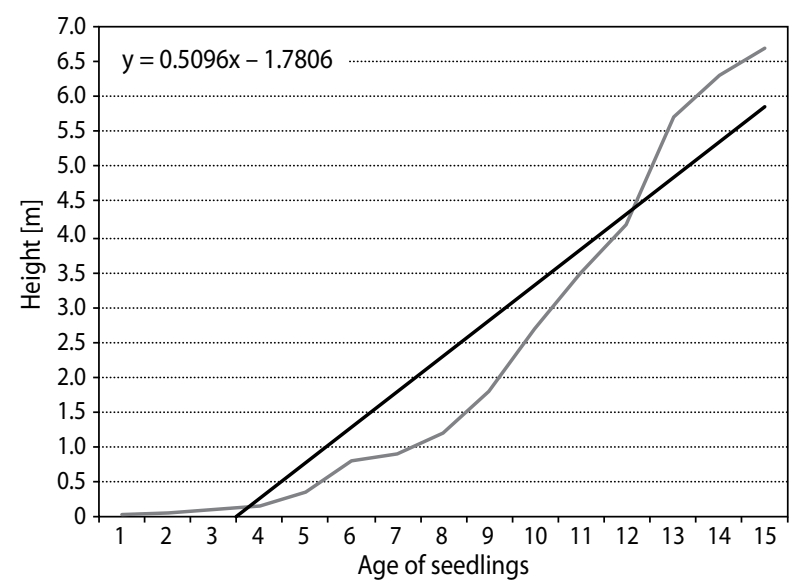

Figure 5. Stand development under the height of the Sorbus torminalis self-seeding in fresh oak-woods of Brytavske Forestry

The formation of the root system is shown in Table 5 .

In the first year, the main root deepens by $14.5-17.0 \mathrm{~cm}$. The growth energy of horizontal roots of 3 year-old self-seedlings increases in comparison with the main ones. In 6-7 year-old self-seeding root system is formed according to the growth conditions, the main root reaches up to $30 \mathrm{~cm}$, the lateral are horizontal and oblique vertical and are much longer than the main root. In the 8-10 year new growth, we see the intense growth and branching of shoots. The root system enters the sphere of the root system of common oak, Norway maple and small-leaved linden, forming a common rhizosphere. A typical feature of this period of development is that, when the top of the shoot is damaged by animals, it gives stool shoots. At the age of 11-15 years, in good light conditions, the top has a well-developed crown, but the diameters of trunks compared to the crown are small $-6-8.6 \mathrm{~cm}$. The root system diameter goes beyond the crown projection.

To study the forest regeneration processes, first of all, the number of new growth and its degree of viability under a shelterwood of the forest stand of different density in the most common forest conditions were determined. For this purpose, 11 permanent sample plots and 31 temporary sample plots were laid. The accounting of regeneration under a shelterwood and on logging was carried out using the methods of Piatnytskyi (1994) and Gorshenin and Shvydenko (1977), according to which, the discount areas of $10 \mathrm{~m}^{2}$ (at the average density of new growth) and $20 \mathrm{~m}^{2}$ (for rare new growth) were laid, which annually determined the species composition of the new growth, its number and age. Based on the data obtained, the success of the new growth was evaluated. Each sample plot described the species richness of grasses and the overall projective coverage of each species with the conversion of its number per one hectare,

Table 5. Structure of Sorbus torminalis root system

\begin{tabular}{|c|c|c|c|c|c|c|c|}
\hline \multirow{2}{*}{$\begin{array}{l}\text { Age group } \\
\text { of trees }\end{array}$} & \multirow{2}{*}{ Quarter, unit } & \multirow{2}{*}{$\begin{array}{c}\text { Total length of roots, } \\
\mathrm{m}\end{array}$} & \multicolumn{3}{|c|}{ Incl. roots, $\mathrm{m} / \%$} & \multirow{2}{*}{$\begin{array}{c}\text { Plant height, } \\
\mathrm{m}\end{array}$} & \multirow{2}{*}{$\begin{array}{l}\text { Growth of shoot } \\
\text { by years, } \mathrm{cm}\end{array}$} \\
\hline & & & horizontal & vertical & obliquely vertical & & \\
\hline 1 year old & $47 / 1$ & 0.37 & $0.11 / 29.8$ & $0.18 / 48 / 6$ & $0.08 / 21.6$ & 0.09 & - \\
\hline 2 year old & $47 / 1$ & 1.57 & $0.16 / 10.0$ & $0.27 / 16.0$ & $1.18 / 74.0$ & 0.13 & $\begin{array}{l}1 \mathrm{st}-5 \\
2 \mathrm{nd}-8\end{array}$ \\
\hline 3 year old & $\begin{array}{l}47 / 1 \\
44 / 3\end{array}$ & $\begin{array}{l}2.78 \\
3.40\end{array}$ & $\begin{array}{c}1.91 / 68.7 \\
1.96\end{array}$ & $\begin{array}{c}0.43 / 15.5 \\
0.49\end{array}$ & $\begin{array}{c}0.44 / 15.8 \\
0.38\end{array}$ & $\begin{array}{l}0.44 \\
0.57\end{array}$ & $\begin{array}{c}1 \mathrm{st}-4 ; 9 \\
2 \mathrm{~d}-11 ; 22 \\
3 \mathrm{~d}-32 ; 26\end{array}$ \\
\hline 4 year old & $\begin{array}{l}47 / 1 \\
44 / 3\end{array}$ & $\begin{array}{l}3.15 \\
3.45\end{array}$ & $\begin{array}{l}2.27 \\
2.51\end{array}$ & $\begin{array}{c}0.56 \\
-\end{array}$ & $\begin{array}{l}0.32 \\
0.94\end{array}$ & $\begin{array}{l}0.61 \\
0.55\end{array}$ & $\begin{array}{l}3 \mathrm{~d}-18 ; 12 \\
4 \mathrm{th}-22 ; 18\end{array}$ \\
\hline 5 year old & $\begin{array}{l}47 / 7 \\
44 / 3\end{array}$ & $\begin{array}{l}3.39 \\
3.69\end{array}$ & $\begin{array}{c}2.4 \\
1.76\end{array}$ & $\begin{array}{c}0.57 \\
-\end{array}$ & $\begin{array}{l}0.42 \\
1.40\end{array}$ & $\begin{array}{l}0.66 \\
0.53\end{array}$ & $\begin{array}{l}4 \text { th }-16 ; 18 \\
5 \text { th }-21 ; 17\end{array}$ \\
\hline 7 year old & $44 / 3$ & 4.49 & 2.61 & 0.32 & 1.56 & 0.82 & $\begin{array}{l}\text { 6th }-12 \\
7 \text { th }-18\end{array}$ \\
\hline 8 year old & $44 / 3$ & 5.00 & 3.0 & 0.51 & 1.54 & 1,90 & 8 th -53 \\
\hline 15 year old & $34 / 11$ & 11.2 & 6.83 & 0.47 & 3.10 & 6.20 & $\begin{array}{l}14 \text { th }-70 \\
15 \text { th }-62\end{array}$ \\
\hline
\end{tabular}


height measurements and determination of age, density, viability and nature of placement on the area. A biological feature of natural renewal is the ability to maintain long-term viability under the lack of light, but after five years, the self-seeding comes out when Carpinus betulus or Fraxinus excelsior prevails in the undergrowth and the crops have high grass cover. The vegetative renewal of $S$. torminalis in natural plantations was not detected.

One of the measures for the preservation and restoration of wild service tree is the cultivation of this widespread fruit and berry plant in the fruit and ornamental horticulture of Ukraine.

\section{Conclusions}

1. According to the indices of the studied area, the South Podolsk Forest-Steppe of Ukraine, it is stated that the stands with Sorbus torminalis have better values of the species distribution in comparison with the central, western and southern parts of the range. This territory is the northeast boundary of the species' natural growth as the natural associate species of Quercus robur.

2. The main causes of loss of S. torminalis new growth under a shelterwood are the high completeness, the significant spread of C. betulus and A. platanoides, which are fast-growing species and suppress the new growth of $Q$. robur and $S$. torminalis.

3. The increased process of aridization in recent years, biological and physiological features of seeds, loss of reproductive trees in the stands has caused the low viability of the Sorbus torminalis self-sowing. The very rare seed reproduction makes the species extremely vulnerable to the effects of any negative factors.

4. The preservation of $S$. torminalis in the region will be facilitated by measures aimed at restoring the composition and structure of stands under the root type, as well as introducing it into forest crops and using them in landscape design as highly ornamental tree species.

5. Implementation of the Sorbus torminalis Protection and Preservation Program in the Protected Areas enables rapid response to external and internal changes, attracting interested people, organizations and resources for the regeneration and maintenance of natural phytocoenoses and the sustainable development of the regions.

\section{LiST OF ABBREVIATIONS}

$\mathrm{Ca}$ - common ash

$\mathrm{Ch}$ - common hornbeam

$\mathrm{Chl}$ - common hazel

Co- common oak

$\mathrm{Fe}$ - field elm

Fm - field maple

Wch - wild cherry

Wst - wild service tree

LSD - least significant difference

\section{ReferenCes}

Alekseev, A.S. 2003. Monitoring of forest ecosystems (in Russian). LTA, St. Petersburg, Russia.

Angelone, S., Hilfiker, K., Holderegger, R., Bergamini, A., Hoebee, S.E. 2007. Regional population dynamics define the local genetic structure in Sorbus torminalis. Molecular Ecology, 16 (6), 1291-1301. DOI: https://doi.org/10.1111/j.0962-1083.2006.03202.x

Anuchin, N.P. 1977. Forest inventory (in Russian). Lesnaya Promyshlenost, Moskva, Russia.

Bondar, A.O. 2002. Wild service tree in forest plantations (in Ukrainian). Vinnytca, Ukraine.

Bondar, A.O., Hordiyenko, M.I. 2006. Formation of forest plantations in the oak groves of Podillya (in Ukrainian). Kyiv, Ukraine.

Budzhak, V.V. 1996. Wild service tree (Sorbus torminalis (L.) Crantz) in north Bukovyna and north Bessarabiya (chronology, bioecology, protection) (in Ukrainian). Ukraine.

Chronicle of nature of NPP Karmelukove Podillya T.5. 2018. Chechelnyk, Ukraine.

Demesure, B., Le Guerroué, B, Lucchi, G., Prat, D., Petit, R.-J. 2000. Genetic variability of a scattered temperate forest tree: Sorbus torminalis L. (Crantz). Annals of Forest Science, 57 (1), 63-71. DOI: https://doi.org/10.1051/forest:2000101

Dubyna, A.A. 1972. Forest litter as a component of natural forest biogeocenoses of south-eastern part of Ukraine and gyrcenov forests of Moldova (in Russian). Moskva, Russia. 
Gorshenin, N.M., Shvydenko, A.I. 1977. Forestry (in Russian). Vyshaya shkola, Lviv, Ukraine.

Homilevskiy, V. 1887. Wild service tree (Pyrus torminalis Dhuamel - Russian, forgotten but excellent species (in Ukrainian). Lesnoj Zhurnal, 4, 31-36.

Hordienko, M.I., Bondar, A.O., Krynytskiy, G.T. 2006. Forest plantations of Vinnycya region (in Ukrainian). Kyiv, Ukraine.

Hordienko, M.I., Koretskiy, D.S., Maurer, V.M. 1995. Forest cultures (in Ukrainian). Silgosposvita, Kyiv, Ukraine.

Hordienko, M.I., Slapak, V.P. 1998. Steppe forests of Ukraine (in Ukrainian). PrestyzhInform, Lviv, Ukraine.

Ivanchenko, S.I. 1952. Wild service tree - valuable species for forest plantations in Steppe (in Russian). Lesnoye Hozyaystvo, 8, 41-46.

Kolisnichenko, O.M. 2004. Sesonal biorhythms and winter hardiness of woody plants (in Ukrainian). Fitosociocentr, Kyiv, Ukraine.

Lavrynenko, D.D. 1965. Relationship of woody species in different types of forest (in Russian). Lesnaya Promyshllenost, Moskva, Russia.

Lejntyak, G.P., Gordenko, M.I., Krynytskiy, G.T. 2003. Ecological role of wild growth of fruit plants in forest plantations (in Russian). Lesnaya Promyshlenost, Moskva, Russia.

Mahmet, B.M. 1965. Culture of wild service tree in Ukrainian RSR (in Ukrainian). Urozhay, Kyiv, Ukraine, 3-38.

Management of protected forests of Ukraine (in Ukrainian). 2003. Pid zag. red. akad. NAN Ukrainy Shelyaga-Sosonka U.R. Kyiv, Ukraine.

Methodical recommendations from conducting of field work at forest monitoring sites of I level (in Ukrainian). 2011. UkrNDILGA, Kharkiv, Ukraine.

Oddou-Muratorio, S., Klein, E.K., Austerlitz, F. 2005. Pollen flow in the wildservice tree, Sorbus torminalis (L.) Crantz. II. Pollen dispersal and heterogeneity in mating success inferred from parentoffspring analysis. Molecular Ecology, 14 (14), 4441-4452. DOI: https://doi.org/10.1111/j.1365294X.2005.02720.x

Osipov, M.U., Leontyak, G.P. 2013. New fruit and decorative plants (in Ukrainian). Nauk. visnyk NLTU Ukrainy, 4, 112-117.
Pyatnytskyi, S.S. 1955. Reforestation in conditions of Left-Bank Forest-Stappe (in Russian). Lesorazvedeniye i vozobnovleniye,. 45, 3-23.

Pogrebnyak P.S. 1993. Forest ecology and typology of forests (in Ukrainian). Naukova duumka, Kyiv, Ukraine, 136-141.

Rasmussen, K.K., Kollmann, J. 2004. Poor sexual reproduction on the distribution limit of the rare tree Sorbus torminalis. Acta Oecologica, 25 (3), 211-218. DOI: https://doi.org/10.1016/j.actao.2004.02.001

Shpak, N.P. 2017. Age plantings of oak in NPP «Karmelukove Podillya» (in Ukrainian). Materialy konf. Perspektyvy rozvytku lisovogo i sadovo-parkovogo gospodarstva. Uman, Ukraine, 47-49.

Shpak, N.P. 2017. Sorbus torminalis L. in forest plantations of NPP «Karmelukove Podillya» (in Ukrainian). Materials of IV Mizhnarodnoi naukovo-praktychnoi konferencii. Kyiv, Ukraine, 116-118.

Shpak, N.P. 2018. Inventory of Sorbus torminalis L. Crantz as a necessary measure for its protection and preservation (in Ukrainian). Internaional Multidisciplinary Conference "Key Issues of Education and Sciences: Development Prospects for Ukraine and Poland" (20-21 Juli, 2018). Stalowa Wola, Republic of Poland, 76-78.

Shpak, N.P., Slapak, V.P., Leontyak, G.P. 2017. Features of formation of root system of Sorbus torminalis (L.) Crantz in forest plantations natural origin of SouthPodilsk Forest-Steppe of Ukraine (in Ukrainian). Nauk. visnyk NLTU Ukrainy, 27 (6), 55-58.

Shvydenko, A.Y. 1987. Informative and reference material for forest inventory of Ukraine and Moldova (in Ukrainian). Urozhay, Kuiv, Ukraine.

Soldatov, A.G., Tukov, S.U. Turkevich, M.V. 1960. Forests of Ukraine (in Ukrainian). Ukr. Acad. silgosp. nauk, Kyiv, Ukraine.

Svyrydenko, V.E., Kyrychok, L.S., Babich, O.G. 2006. Practicum from forestry (in Ukrainian). Aristey, Kyiv, Ukraine.

Zerov, D.K. 1965. Determinant of plants of Ukraine (in Ukrainian). Kyivska Knyzhkova Fabryka, Kyiv, Ukraine.

Zlobin, U.A. 1989. Principles and methods of studying coenotic populanions of plants (in Russian). Kazanskiy universitet, Kazan, Russia. 